\title{
Co-circulation of Usutu virus and West Nile virus in a reed bed ecosystem
}

\author{
Ivo Rudolf', Tamás Bakonyi ${ }^{2,3}$, Oldřich Šebesta', Jan Mendel', Juraj Peško ', Lenka Betášová', Hana Blažejová',
} Kristýna Venclíková ${ }^{4}$ Petra Straková ${ }^{4}$, Norbert Nowotny ${ }^{3,5}$ and Zdenek Hubálek ${ }^{\text {* }}$

\begin{abstract}
Background: Mosquito-borne flaviviruses are a major public health threat in many countries worldwide. In Central Europe, West Nile virus (WNV) and Usutu virus (USUV), both belonging to the Japanese encephalitis virus group (Flaviviridae) have emerged in the last decennium. Surveillance of mosquito vectors for arboviruses is a sensitive tool to evaluate virus circulation and consequently to estimate the public health risk.

Methods: Mosquitoes (Culicidae) were collected at South-Moravian (Czech Republic) fishponds between 2010 and 2014. A total of 61,770 female Culex modestus Ficalbi mosquitoes, pooled to 1,243 samples, were examined for flaviviruses by RT-PCR.

Results: One pool proved positive for USUV RNA. Phylogenetic analysis demonstrated that this Czech USUV strain is closely related to Austrian and other Central European strains of the virus. In addition, nine strains of WNV lineage 2 were detected in $C X$. modestus collected in the same reed bed ecosystem.

Conclusions: This is the first detection of USUV in CX. modestus. The results indicate that USUV and WNV may co-circulate in a sylvatic cycle in the same habitat, characterised by the presence of water birds and $C X$. modestus mosquitoes, serving as hosts and vectors, respectively, for both viruses.
\end{abstract}

Keywords: Culex modestus, Usutu virus, West Nile virus, Flavivirus, Arbovirus, Surveillance, Mosquitoes

\section{Background}

Usutu virus (USUV) is a mosquito-borne virus (Japanese encephalitis group, genus Flavivirus; family Flaviviridae) that was originally isolated in Africa. In or before 1996, the virus was introduced to Europe [1]. It circulates in nature between birds (as amplifying hosts) and bird-feeding mosquitoes, principally Culex spp., as vectors. USUV is taxonomically and ecologically very similar to West Nile virus (WNV) $[2,3]$. Contrary to WNV, USUV has rarely caused human disease - only in immunocompromised persons [4]. However, USUV antibodies were recently reported in three patients with neuroinvasive disease in Croatia [5].

\footnotetext{
* Correspondence: zhubalek@brno.cas.cz

'Institute of Vertebrate Biology, v.v.i., Academy of Sciences, Květná 8, 60365 Brno, Czech Republic

Full list of author information is available at the end of the article
}

In the Czech Republic, two strains of USUV were isolated from dead blackbirds (Turdus merula) in Brno, 2011 and 2012 [6]. In addition, specific neutralizing antibodies against USUV were found in common coots (Fulica atra) in Moravia [7, 8].

Neutralizing antibodies against WNV were rarely found in the local human population, but five cases of West Nile fever in humans were reported after heavy floods in 1997 [9]. More frequently WNV antibodies occur in apparently healthy wild birds in this region [7]. Three identical strains of WNV (proposed genomic lineage 3: Rabensburg) were isolated from Culex pipiens and Aedes rossicus mosquitoes in 1997, 1999 and 2006 [10]. In a previous study, we reported four strains of lineage $2 \mathrm{WNV}$ from Culex modestus mosquitoes collected in reed beds at South-Moravian fishponds (Czech Republic) during August 2013 [11].

\section{() Biomed Central}

(c) 2015 Rudolf et al. Open Access This article is distributed under the terms of the Creative Commons Attribution 4.0 International License (http://creativecommons.org/licenses/by/4.0/), which permits unrestricted use, distribution, and reproduction in any medium, provided you give appropriate credit to the original author(s) and the source, provide a link to the Creative Commons license, and indicate if changes were made. The Creative Commons Public Domain Dedication waiver (http://creativecommons.org/publicdomain/zero/1.0/) applies to the data made available in this article, unless otherwise stated. 
Within the scope of the joint European EDENext project we extended our virological surveillance of local $C x$. modestus mosquitoes for pathogenic flaviviruses, including USUV.

\section{Methods}

\section{Study sites}

Female mosquitoes were collected using CDC minilight $\mathrm{CO}_{2}$-baited traps (EVS $\mathrm{CO}_{2}$ Mosquito Trap, BioQuip Products Inc., United States) at three study sites (fishponds "Nesyt" and "Nový" near Sedlec, and "Mlýnský" near Lednice: $48^{\circ} 47^{\prime} \mathrm{N}$ and $16^{\circ} 42^{\prime}-16^{\circ} 49^{\prime} \mathrm{E}$; $175-177 \mathrm{~m}$ a.s.l.) in the district of Břeclav, South Moravia, Czech Republic, as described in a preceding paper [11], during July and August from 2010 to 2014. All study sites are characterised by reed bed ecosystem (Phragmites communis alliance) situated at the littoral zone of the fishponds (Fig. 1). Thirty species of birds have been recorded breeding in the reed bed, and an additional 54 wild wetland and terrestrial bird species visit this ecosystem during seasonal movements [12]. A characteristic mosquito species for this ecosystem in this part of Moravia is Cx. modestus. From an epidemiological point of view it is noteworthy that all study sites represent favourite recreational areas during the summer season.

\section{Mosquito processing, RNA extraction, PCR and sequencing} Caught insects were transported to the laboratory in cooled flasks, and stored at $-65{ }^{\circ} \mathrm{C}$ until examination. Mosquitoes were determined on a chilled table under a stereomicroscope according to an entomological key [13], and monospecific pools consisting of up to 50 female Cx. modestus (other species were not tested in this study) were homogenized in $1.5 \mathrm{ml}$ of cooled phosphate-buffered saline $\mathrm{pH} 7.4$ supplemented with $0.4 \%$ bovine serum albumin (Sigma) and antibiotics (PBS-BSA), and centrifuged.

RNA was extracted from $140 \mu \mathrm{l}$ mosquito homogenates using the QIAamp Viral RNA Mini Kit (Qiagen, Hilden, Germany) according to the manufacturer's instructions. Generic oligonucleotide primers targeting the NS5 region of flaviviruses were used for screening purposes [14]. Samples positive by the above panflavivirus PCR were subjected to USUV $[15,16]$ as well as WNV [11] -specific RT-PCR assays for amplification of overlapping genome regions. Amplification

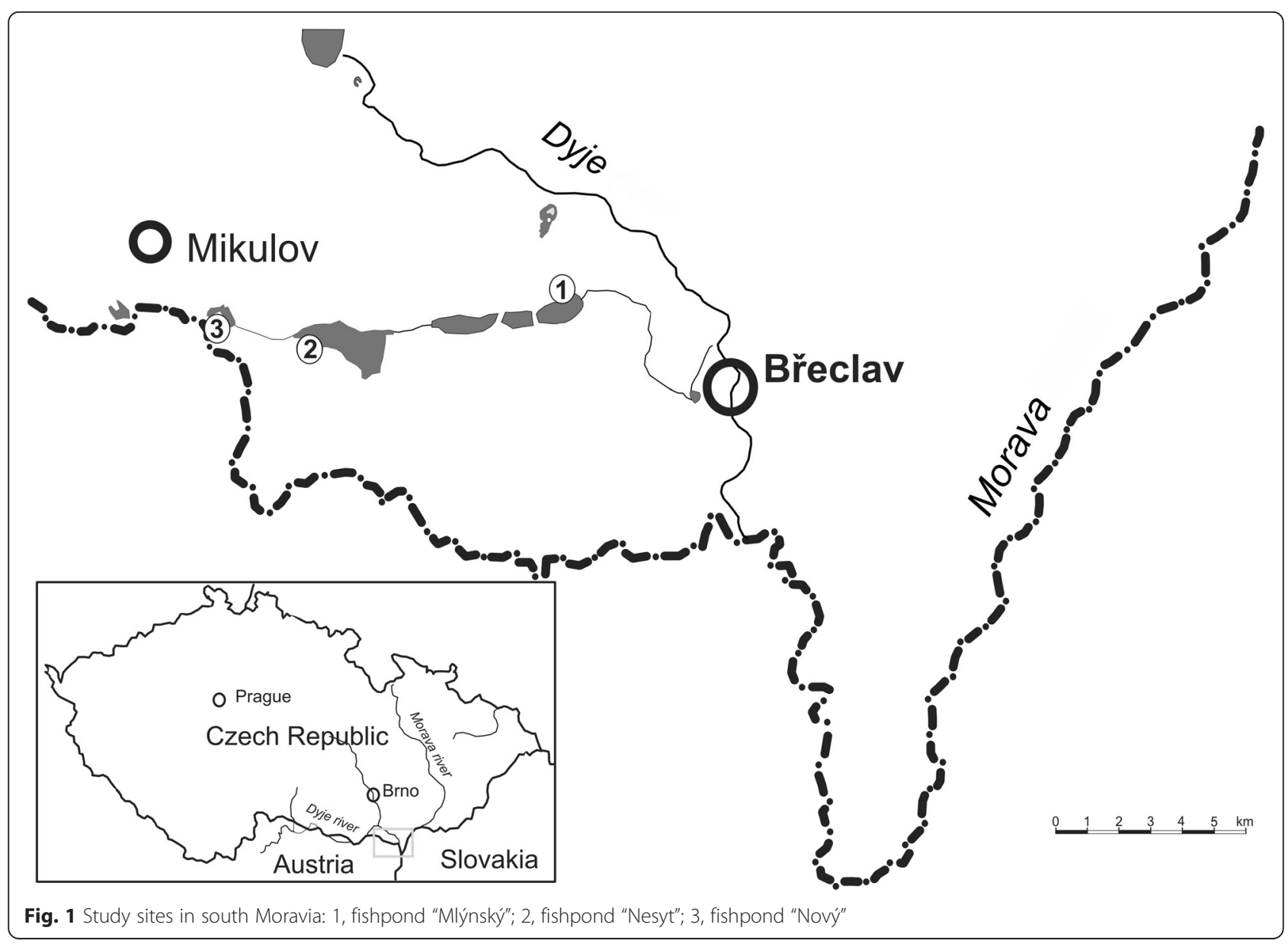


products were directly sequenced (Microsynth, Balgach, Switzerland); the sequences were aligned and compiled, and identified by BLAST search against GenBank database.

\section{Phylogenetic analyses}

Phylogenetic and molecular evolutionary analyses of concatenated sequences were conducted using neighborjoining, maximum likelihood, minimum evolution, UPGMA and maximum parsimony algorithms (MEGA version 6, with 1000 replicates for bootstrap testing).

\section{Virus isolation}

The original mosquito homogenates of PCR-positive samples were inoculated intracerebrally (i.c., $20 \mu \mathrm{l}$ ) into specific pathogen free suckling ICR mice (SM). Brains of dead animals were homogenized in PBS-BSA, centrifuged, and passaged (i.c.) in a new batch of SM. Bacterial sterility of the suspensions was checked in meat-peptone and thioglycollate broths incubated at $37{ }^{\circ} \mathrm{C}$ [10]. All experiments with laboratory mice were conducted in accordance with the Czech Animal Protection Act no. 246/1992, and the protocols were approved by the Institutional and Central Care and Use Committees at the Academy of Sciences of the Czech Republic in Prague and by the Veterinary Service in Brno. The facility is accredited by the Czech National Committee on Care and Use of Laboratory Animals (6630/2008-10001).

\section{Results and discussion}

A total of 61,770 female $C x$. modestus mosquitoes in 1,243 pools (including 32,500 individuals in 650 pools, collected in the same place and evaluated in 2014 [11]) were examined for flaviviruses by RT-PCR (Table 1 ). USUV RNA was detected in one pool (\#13-662) of $C x$. modestus collected at Mlýnský fishpond on 7 August 2013; the overall minimum prevalence rate of USUV in $C x$. modestus was therefore 0.016 per 1,000 mosquitoes. When the mosquito homogenate \#13-662 was inoculated into $13 \mathrm{SM}$, two of them were missing on day 4 p.i. (most probably cannibalized by the mother after they became ill or died). Repeated inoculation of another litter of $12 \mathrm{SM}$ with the same homogenate was negative, all SM survived.
A total of 4218 nucleotides in five genome regions (corresponding to $38 \%$ of the genome) of the USUVpositive pool \#13-662 was determined. It revealed 12 substitutions when compared to the complete genome sequence of the USUV Vienna strain from 2001 ([2, 15]; GenBank: AY453411), thus indicating a high (99.7 \%) nucleotide identity rate: genome region nt 1610-2980 (E-NS1; 1371 nt): 1 substitution; genome region 3021-3685 (NS1-NS2a; 665 nt): 2 substitutions; genome region 4444-5615 (NS2b-NS3; $1172 \mathrm{nt}$ ): 6 substitutions; genome region 6582-6907 (NS4a-2 K; 326 nt): no substitution; genome region 7351-8034 (NS4b-NS5; 684 nt): 3 substitutions. Nucleotide sequences were deposited in GenBank database under accession number KT445930. The phylogenetic relationship of the Czech $C x$. modestus-derived USUV strain with other USUV strains is displayed in Fig. 2. Neighbor-joining, maximum likelihood, minimum evolution, UPGMA and maximum parsimony algorithms revealed almost identical trees; the phylogeny shown in Fig. 2 is based on the neighbor-joining algorithm. The Czech USUV clustered together with Austrian and Hungarian viruses detected between 2001 and 2005 [16]. However, recently identified USUV strains from Germany and Italy formed separate branches.

Also in South Moravia (Czech Republic), USUV strains had been previously isolated, namely from blackbirds, which were found dead in 2011 and 2012, respectively [6]. The 2011 isolate was sequenced in two regions: partial E + NS1 (GenBank: JX236666) and partial NS5-5'UTR (GenBank: JX236667). In the E + NS1 region there is a $1371 \mathrm{nt}$ overlap (nts 1610-2980 referring to the USUV sequence AY453411) between the 2011 blackbird-derived USUV sequence [6] and the $2013 \mathrm{Cx}$. modestus-derived sequences (this paper), and in the $\mathrm{E}$ protein coding region of this overlap the two genomes differ in (only) three nucleotides at positions 1872 ( $\mathrm{T}$ vs. C), 2322 (C vs. T), and 2419 (C vs. $\mathrm{T})$, resulting in a $99.78 \%$ identity between the two Czech USUV strains in this genomic region; none of the substitutions lead to putative amino acid changes.

Furthermore, WNV genomic lineage 2 (WNV-2) was detected in nine pools of $C x$. modestus mosquitoes collected in August 2013: \#13-104 (collected at Nový fishpond); \#13-329 (coll. at Nesyt fishpond); \#13-479 (coll. at Mlýnský fishpond); \#13-502 (coll. at Mlýnský fishpond) (these four records were reported in a

Table 1 Numbers of female Culex modestus mosquitoes examined for flaviviruses in individual years and at three study sites

\begin{tabular}{lllllll}
\hline Fishpond & 2010 & 2011 & 2012 & 2013 & 2014 & Total \\
\hline Nesyt & $11(1)$ & $1,304(27)$ & $2,649(54)$ & $8,400(168)$ & $100(2)$ & $12,464(252)$ \\
Nový & 0 & 0 & 0 & $10,835(217)$ & $206(4)$ & $11,041(221)$ \\
Mlýnský & $5,450(109)$ & $533(11)$ & $4,079(82)$ & $22,050(441)$ & $6,153(127)$ & $38,265(770)$ \\
Total & $5,461(110)$ & $1,837(38)$ & $6,728(136)$ & $41,285(826)$ & $6,459(133)$ & $61,770(1243)$ \\
\hline
\end{tabular}

Number of pools is shown in parentheses 


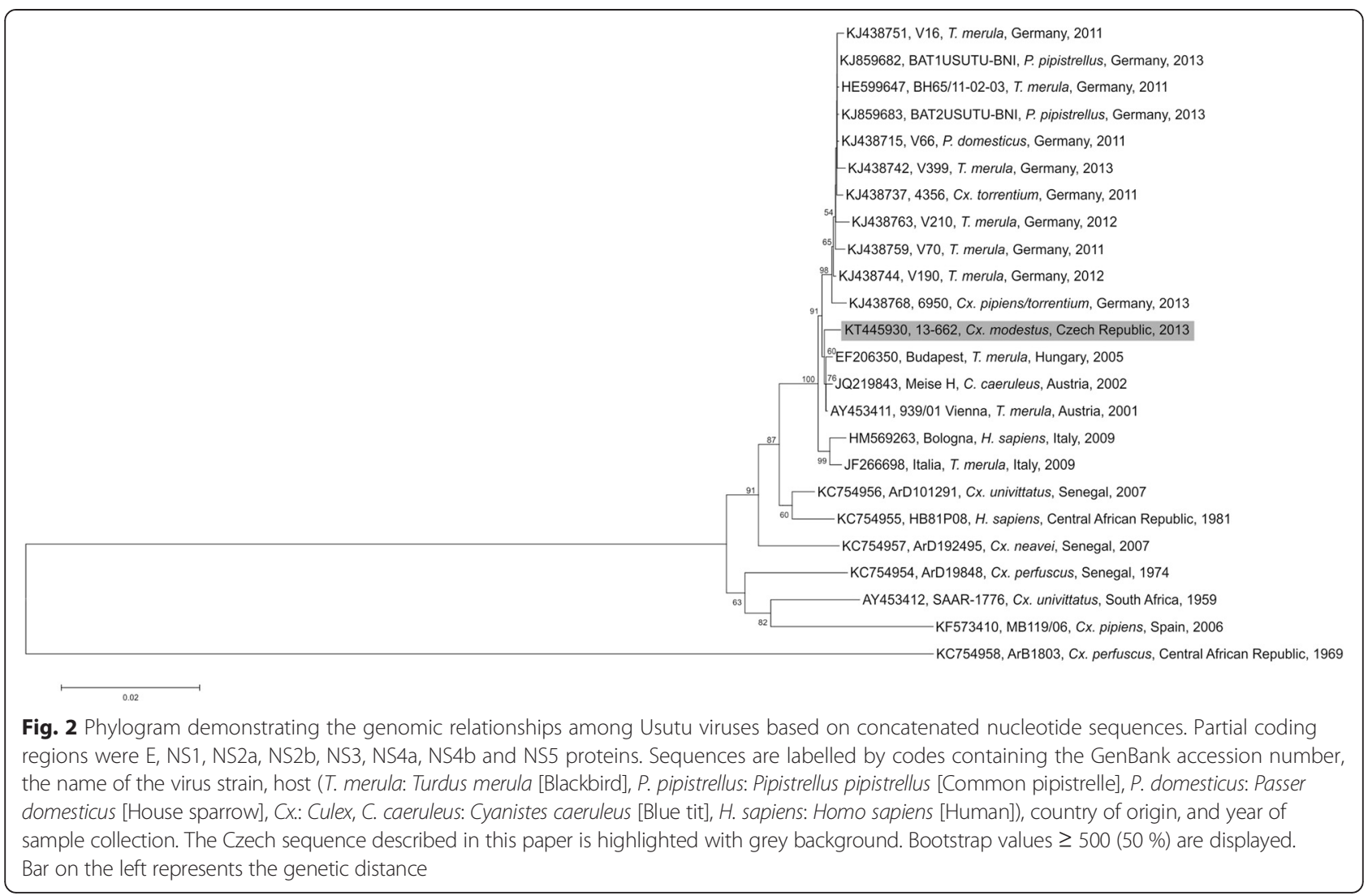

previous study: [11]); \#13-670 (coll. at Mlýnský fishpond); \#13-743 (coll. at Nesyt fishpond); \#13-853 (coll. at Mlýnský fishpond); \#13-859 (coll. at Nesyt fishpond); \#13-862 (coll. at Nesyt fishpond); the overall minimum prevalence rate of WNV in Cx. modestus was therefore 0.146 per 1,000 mosquitoes, about ten times higher than that for USUV. All WNV RNA positive original mosquito homogenates were then inoculated into SM. While the homogenates \#13-329, \#13-670, \#13-743, and \#13-853 did not kill any mice, the five others did: \#13104 killed 6 of 11 inoculated SM within 7-8 days post inoculation (DPI), average survival time (AST) of SM was 7.7 days; \#13-479 killed 8 of 9 inoculated SM (6-7 DPI; AST $6.1 \mathrm{~d})$; \#13-502 killed specifically 7 of $10 \mathrm{SM}$ (6-8 DPI; AST 6.4 d); \#13-859 killed 5 of 11 SM (6-7 DPI; AST $6.4 \mathrm{~d}$ ); and \#13-862 killed all 11 inoculated SM (6-7 DPI; AST 6.7 d).

To the best of the authors' knowledge, this is the first detection of USUV in Cx. modestus. It indicates that USUV may co-circulate with WNV in certain habitats this phenomenon was demonstrated previously in northern Italy, where the principal mosquito vector of USUV (and WNV as well) is Cx. pipiens [3, 17-21]. A comprehensive review on the co-circulation of the two arboviruses in Europe has recently been written [22]. Contrary to northern Italy, where USUV occurs in Culex mosquitoes much more frequently than WNV, reverse proportion was found in South Moravia in this study.

Interestingly, both viruses (USUV, WNV) were detected in South Moravia in 2013, but not in the years 2010, 2011, 2012 and 2014. This result could be affected by the number of $C x$. modestus mosquitoes examined in individual years, which was much higher in 2013 than in the other years (Table 1). Moreover, mosquitoes were not collected in August 2014 (only in July).

Our previous finding that the common coot (Fulica atra) relatively often reveals specific antibodies to USUV $[7,8]$ might indicate a specific role of this avian species in the circulation of USUV in wetlands.

\section{Conclusions}

This is the first detection of USUV in Cx. modestus. The results indicate that USUV and WNV may co-circulate in a sylvatic cycle in the same habitat, characterised by the presence of water birds and $C x$. modestus mosquitoes, serving as hosts and vectors, respectively, for both viruses. The present finding suggests that USUV (similar to WNV) may circulate in two types of ecosystems: (i) sylvatic cycle between $C x$. pipiens/ $C x$. modestus and water birds - such as coots, based on a previous serosurvey study [7]; (ii) urban cycle involving $C x$. pipiens and blackbirds or occasionally some other synanthropic avian species. 


\section{Competing interests}

The authors declare that they have no competing interests.

\section{Authors' contributions}

IR and ZH designed, coordinated and supervised the study, performed laboratory testing, and wrote the manuscript; TB and JM carried out sequence analysis, processed phylogenetic data, read and revised the manuscript; LB, HB, JP, PS and KV trapped the mosquitoes, performed molecular analyses, read and revised the manuscript; OS trapped the mosquitoes and performed their identification, read and revised the manuscript; NN analysed data, wrote and revised the manuscript. All authors read and approved the final manuscript.

\section{Acknowledgements}

This study was funded by the EU grant FP7-261504 EDENext. The publication is catalogued by the EDENext Steering Committee as EDENext428. The contents of this paper are the sole responsibility of the authors and do not necessarily reflect the views of the European Commission.

\section{Author details}

${ }^{1}$ Institute of Vertebrate Biology, v.v.i., Academy of Sciences, Květná 8, 60365 Brno, Czech Republic. ${ }^{2}$ Department of Microbiology and Infectious Diseases, Faculty of Veterinary Science, Szent István University, Budapest, Hungary. ${ }^{3}$ Viral Zoonoses, Emerging and Vector-Borne Infections Group, Institute of Virology, University of Veterinary Medicine, Vienna, Austria. ${ }^{4}$ Department of Experimental Biology, Faculty of Science, Masaryk University, Brno, Czech Republic. ${ }^{5}$ Department of Microbiology and Immunology, College of Medicine and Health Sciences, Sultan Qaboos University, Muscat, Oman.

\section{Received: 27 August 2015 Accepted: 3 October 2015}

Published online: 12 October 2015

\section{References}

1. Weissenböck H, Bakonyi T, Rossi G, Mani P, Nowotny N. Usutu virus, Italy, 1996. Emerg Infect Dis. 2013;19:274-7.

2 Weissenböck H, Kolodziejek J, Url A, Lussy H, Rebel-Bauder B, Nowotny N. Emergence of Usutu virus, an African mosquito-borne flavivirus of the Japanese encephalitis virus group, Central Europe. Emerg Infect Dis. 2002;8:652-6.

3. Calzolari M, Bonilauri P, Bellini R, Albieri A, Defilippo F, Maioli G, et al. Evidence of simultaneous circulation of West Nile and Usutu viruses in mosquitoes sampled in Emilia-Romagna region (Italy) in 2009. PLoS One. 2010;5(12):e14324

4. Vazquez A, Jimenez-Clavero M, Franco L, Donoso-Mantke O, Sambri V, Niedrig M, et al. Usutu virus - potential risk of human disease in Europe. Euro Surveill. 2011;16:22-6.

5. Vilibic-Cavlek T, Kaic B, Barbic L, Pem-Novosel I, Slavic-Vrzic V, Lesnikar V, et al. First evidence of simultaneous occurrence of West Nile virus and Usutu virus neuroinvasive disease in humans in Croatia during the 2013 outbreak. Infection. 2014;42:689-95.

6. Hubálek Z, Rudolf I, Čapek M, Bakonyi T, Betášová L, Nowotny N. Usutu virus in blackbirds (Turdus merula), Czech Republic, 2011-2012. Transbound Emerg Dis. 2014;61:273-6.

7. Hubálek Z, Halouzka J, Juřicová Z, Šikutová S, Rudolf I, Honza M, et al. Serologic survey of birds for West Nile Flavivirus in southern Moravia (Czech Republic). Vector Borne Zoonot Dis. 2008;8:659-66.

8. Straková P, Šikutová S, Jedličková P, Sitko J, Rudolf I, Hubálek Z. The common coot as sentinel species for the presence of West Nile and Usutu flaviviruses in Central Europe. Res Vet Sci. 2015;102:159-61.

9. Hubálek Z, Savage HM, Halouzka J, Juřricová Z, Sanogo YO, Lusk S. West Nile virus investigations in South Moravia, Czechland. Viral Immunol. 2000;13:427-33.

10. Hubálek Z, Rudolf I, Bakonyi T, Kazdová K, Halouzka J, Šebesta O, et al. Mosquito (Diptera: Culicidae) surveillance for arboviruses in an area endemic for West Nile (lineage Rabensburg) and Tahyna viruses in Central Europe. J Med Entomol. 2010;47:466-72.

11. Rudolf I, Bakonyi T, Šebesta O, Mendel J, Peško J, Betášová L, et al. West Nile virus lineage 2 isolated from Culex modestus mosquitoes in the Czech Republic, 2013: expansion of the European WNV endemic area to the North? Euro Surveill. 2014;19(31):2-5.
12. Hubálek Z, Juřicová Z, Halouzka J, Pellantová J, Hudec K. Arboviruses associated with birds in southern Moravia, Czechoslovakia. Acta Sci Nat Brno. 1989;23(7):1-50.

13. Becker N, Petrič D, Zgomba M, Boase C, Madon M, Dahl C. Mosquitoes and their control. 2nd ed. Heidelberg: Springer; 2010.

14. Scaramozzino N, Crance JM, Jouan A, DeBriel DA, Stoll F, Garin D. Comparison of flavivirus universal primer pairs and development of a rapid, highly sensitive heminested reverse transcription-PCR assay for detection of flaviviruses targeted to a conserved region of the NS5 gene sequences. J Clin Microbiol. 2001;39:1922-7.

15. Bakonyi T, Gould EA, Kolodziejek J, Weissenböck H, Nowotny N. Complete genome analysis and molecular characterization of Usutu virus that emerged in Austria in 2001: comparison with the South African strain SAAR-1776 and other flaviviruses. Virology. 2004;328:301-10.

16. Bakonyi T, Busquets N, Nowotny N. Comparison of complete genome sequences of Usutu virus strains detected in Spain, Central Europe, and Africa. Vector Borne Zoonot Dis. 2014;14:324-9.

17. Calzolari M, Galbani P, Bellini R, Defilippo F, Pierro A, Albieri A, et al. Mosquito, bird and human surveillance of West Nile and Usutu viruses in Emilia-Romagna region (Italy) in 2010. PLoS One. 2012;7(5):e38058.

18. Calzolari M, Bonilauri P, Bellini R, Albieri A, Defilippo F, Tamba M, et al. Usutu virus persistence and West Nile virus inactivity in the Emilia-Romagna region (Italy) in 2011. PLoS One. 2013;8(5):e63978.

19. Busani L, Capelli G, Cecchinato M, Lorenzetto M, Savini G, Terregino C, et al. West Nile virus circulation in Veneto region in 2008-2009. Epidemiol Infect. 2011;139:818-25.

20. Cerutti F, Giacobini M, Mosca A, Grasso I, Rambozzi L, Rossi L, et al. Evidence of mosquito-transmitted flavivirus circulation in Piedmont, north-western Italy. Parasit Vectors. 2012;5:99.

21. Pautasso A, Desiato R, Bertolini S, Vitale N, Radaelli MC, Mancini M, et al. Mosquito surveillance in northwestern Italy to monitor the occurrence of tropical vector-borne diseases. Transbound Emerg Dis. 2013;60 Suppl 2:154-61.

22. Nikolay B. A review of West Nile and Usutu virus co-circulation in Europe: how much do transmission cycles overlap? Trans Roy Soc Trop Med Hyg. 2015;doi:10.1093/trstmh/trv066.

\section{Submit your next manuscript to BioMed Central and take full advantage of:}

- Convenient online submission

- Thorough peer review

- No space constraints or color figure charges

- Immediate publication on acceptance

- Inclusion in PubMed, CAS, Scopus and Google Scholar

- Research which is freely available for redistribution 